\title{
Therapeutic Efficiency of Aristolochic acid on Oral cancer Induced Experimental Rats
}

\author{
Mariappan Senthilkumar \\ PG and Research Department of Botany, Government Arts College, Dharmapuri - 636 705, Tamil Nadu, India.
}

\begin{abstract}
Aristolochia indica is one of the important medicinal plant sources of bioactive compound aristolochic acid (AA). The compound was found to produce cytotoxicity at higher doses, thus AA was examined for therapeutic efficacy against 4-nitroquinoline 1-oxide (4-NQO) induced oral cancer. Purity of the isolated AA was assayed using $U V, I R, N M R$, Mass spectral studies were revealed that the maximum wavelength $(254 \mathrm{~nm})$, functional groups and nature $\left(\mathrm{NO}_{2}\right.$ nitro groups and aromatic), the structure $\left(\mathrm{C}_{17} \mathrm{H}_{11} \mathrm{NO}_{7}\right)$ and molecular weight (341.28) of the compound AA. The dose of AA at $10 \mathrm{mg} / \mathrm{kg} \mathrm{b.wt/for} 4$ weeks. Effect of AA on oral cancer was studied by exploiting various biochemical and histological parameters such as Glutathione-S-transferase (GST), Gamma gultamyl transferase (GGT), 5'-Nucleotidase (5'-NT) and Cathepsin D (CD) and glycoconjugates. There was significant increase in GST and significant decrease in other markers and glycoconjugates were observed on AA treatment in oral cancer induced rats. Number of tumors, percentage of tumors and tumor volume was found to be decreased on AA treated rats on oral cancer induced rats. Thus AA was found to modulate therapeutically on oral cancer regression.
\end{abstract}

Keywords:Aristolochia indica, Aristolochic acid, anti cancer, 4-Nitroquinoline-1-oxide, oral cancer, therapeutic efficacy.

\section{Introduction}

Aristolochia indica Linn. (Aristolochiaceae) is a rich source of medicinally important bioactive compound aristolochic acid (AA). Aristolochia is a large genus comprising more than 800 species, most of them twining lians, and is widely distributed in tropical and subtropical regions almost all over the world [1-3]. Aristolochic acid is mainly found in the genus Aristolochia the compound contains organic nitro groups. They are derived from benzylisoquinoline alkaloid precursors [4]. Cell division was inhibited in white blood cells of aristolochic acid treated mice [5]. The isolated AA from the alcoholic extract of the roots of A. indica were tested on day 6 pregnant mice for interceptive activity at the single oral dose of $50 \mathrm{mg} / \mathrm{kg}$ of body weight [6-8]. The cytotoxicity and antiplatelet activity of the isolated AA from A. kankauensis have been studied [9]. AA isolated from A. shimadai acts against of snakebite and by inhibiting phospholipase $\mathrm{A}_{2}$ or other enzymes [10]. Previous studies showed that AA was found to inhibit breast cancer in vitro [11], another study proved AA as a tumor inhibitor [12, 13].

Oral cancer is a common neoplasm worldwide, particularly in developing countries such as India, Srilanka, Vietnam, Philippines and Brazil, where it constitutes up to $25 \%$ of all kinds of cancer [14]. In recent decades, oral cancer incidence and mortality rates have been increasing in the USA, Japan, Germany and Scotland, especially among young males. In the United States, there are 43,000 new cases annually, resulting in 11,600 deaths [15]. Evidence shows that high consumption of fruits and vegetables reduced the risk of oral cancer, suggesting that natural products offer a protective effect against oral cancer [16]. 4-NQO is known to induce multistep carcinogenesis [17]. So it can serve as a good model to investigate oral carcinogenesis. The carcinogenic potential of 4-NQO is now well documented and it has been shown to produce oral squamous cell carcinoma as well as spindle cell sarcoma in various rodent species [18], which is similar to that of humans. Carcinoma is preceded by a sequence of hyperplasia-papilloma / dysplasia - carcinoma, similar to that of human oral cancer. The primary objective of the study is to evaluate the therapeutic efficacy of AA on 4-NQO induced oral cancer.

\section{Materials And Methods}

\section{1, Preparation of Aristolochia extract}

Fresh and aerial parts of A. indica were collected in the wild. Subsequently, the aerial parts and roots of A. indica $(4 \mathrm{~kg})$ were collected and washed thoroughly in running tap water followed by distilled water and then shade dried. The dried plants were powdered using mechanical pulveriser and subjected for extraction and isolation of compounds. After $72 \mathrm{~h}$ soaked in ethanol, they were concentrated in a rotary evaporator to $10 \%$ of its original volume under reduced pressure at $60^{\circ} \mathrm{C}$. The concentrated extracts were used for total acid fraction to isolate the aristolochic acid. The fractionated samples were extracted with chloroform and finally concentrated to $2 \%$ of its original volume and dried in a hot water bath and was loaded into the column with 
chloroform solution was added to a column $(3.0 \times 100 \mathrm{~cm})$ of silicic acid-Celite $545(4: 1,500 \mathrm{~g})$. Initially the column was run with chloroform with the elution rate of $5.0 \mathrm{~mL} / 10 \mathrm{~min}$. The purification of AA was effected by the crystallization of the crude acid from a mixture of dimethylformamide and ethanol [19]. The purified aristolochic acid was kept at $4^{\circ} \mathrm{C}$ until analysis.

\section{2, Sample solution}

The freeze-dried sample was dissolved in $0.1 \mathrm{M}$ potassium phosphate buffer ( $\mathrm{pH}$ 7.4) just before analysis.

\section{3, Chemicals}

Gultathione, 1-chloro-2,4 dinitrobenzene (CDNB), glycine, gamma glutamyl-p-nitroaniline, Aderosine monophosphate, Heamoglobin, Acetyl acetone, cysteine hydrochloride, ethanol, chloroform, sodium bicarbonate, potassium bromide, dimethyl sulfoxide.

\section{4, UV and Visible spectrum}

The UV and visible spectral measurements of purified compound of aristolochic acid isolated from A. indica by column chromatography were taken using Philips Spectrophotometer (model PU 8700) at 360 to $440 \mathrm{~nm}$. To find out the maximum wavelength $\left(\lambda_{\max }\right)$ of the compound.

\section{5, Infra Red spectrum}

The purified compounds of AA isolated from A. indica were used for IR spectral studies. IR spectra were measured with (260 to $440 \mathrm{~nm}$ ) $\mathrm{KBr}$ pellets in FT-IR BRUKER IFS 66V FT-IR, and FT-IR NICOLET IMPACT 400 (USA). To find out the nature of the compound AA.

\section{6, ${ }^{1} \mathrm{H}$ and ${ }^{13} \mathrm{C}$ NMR spectrum}

The purified compound of AA was used for NMR studies. $\mathrm{CDCl}_{3}$ (Deuterated chloroform) and DMSO D6 were the solvents used as internal reference. Spectra were measured in JEOL Model GSX 400 Spectrometer. To find out the structure and functional groups.

\section{7, Mass spectrum}

Mass spectra of the purified compound AA was recorded in FINNIGAN MAT 4230 Mass spectrometer to find out the molecular mass of the isolated compound. To find out the molecular mass of the compound.

\section{8, Anticancer study (experimental protocol)}

Adult male albino rats of Wistar strain weighing $100-120 \mathrm{gms}, 8-12$ weeks of age were chosen as animal model for the study. Animals were purchased from TANUVAS (Chennai, India). The animals were housed, 4 per cage in a room with controlled temperature and humidity with $12 \mathrm{~h}$ light: dark cycles. All the animals were given a standard rat feed (Hindustan Lever Ltd., Bangalore) and tap water ad libitum. The animals were divided into 4 groups.

Group-I: Applied proplylene glycol using No.3 brush on palatal tissue, thrice a week for 12 weeks.

Group-II: Applied 0.5\% 4-NQO (4-nitroquinoline 1-oxide) in propylene glycol same as Group-I for 12 weeks, left for 22 weeks.

Group-III: Aristolochic acid (AA) alone (10 mg/Kg/b.wt.p.o.) for 4 weeks.

Group-IV: 4-NQO applied for 12 weeks same as Group II, after 22 weeks AA administered (10 $\mathrm{mg} / \mathrm{Kg} /$ b.wt.p.o.) for 4 weeks.

After the experimental period, the animals were anesthetized using ether, sacrificed by cervical decapitation. The mouth was cut opened using a surgical knife. The tongue, hard palatal tissue, cheek, and floor of the mouth was excised out and the tissues were washed in ice-cold saline. A small portion of the tongue was

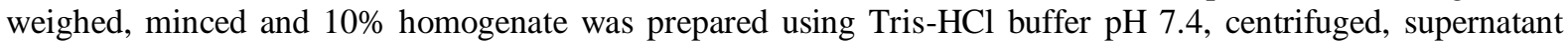
was used for the enzyme assay. A small portion of tongue was fixed in 10\% formalin for histology.

\section{9, Assay of Glutathione-S-transferase (GST)}

Glutathione-S-transferase activity was determined by the method of Habig and Jackobyus [20]. The reaction mixture containing $1.0 \mathrm{~mL}$ of phosphate buffer $(0.3 \mathrm{M}, \mathrm{pH} 6.5), 0.1 \mathrm{~mL}$ of CDNB $(30 \mathrm{mM})$ and $0.1 \mathrm{~mL}$ of enzyme preparation was added and finally made up to $2.5 \mathrm{~mL}$ with water. The reaction mixture was preincubated at $37^{\circ} \mathrm{C}$ for $5 \mathrm{~min} .0 .1 \mathrm{~mL}$ of GSH $(30 \mathrm{mM})$ was added and the change in absorbance was measured at $340 \mathrm{~nm}$ in a Shimadzu UV double beam spectrophotometer. The enzyme activity was expressed as nmoles $\mathrm{CDNB}$ conjugated $/ \mathrm{min} / \mathrm{mg}$ of protein 


\subsection{0, Assay of Gamma Glutamyl transferase (GGT)}

The enzyme was assayed according to the method of Rosalki and Rau [21]. The homogenate $(0.5 \mathrm{~mL})$ was added to the incubation mixture containing $0.5 \mathrm{~mL}$ gamma glutamyl p-nitroaniline, $2.0 \mathrm{~mL}$ of glycyl glycine $(0.1 \mathrm{M})$ and $1.0 \mathrm{~mL}$ (Tris- $\mathrm{HCl}, \mathrm{pH} 8.2$ ) buffer. After incubation of $30 \mathrm{~min}$ at $37^{\circ} \mathrm{C}$, the reaction was arrested by the addition of $1.0 \mathrm{~mL}$ of $10 \%$ acetic acid .The amount of p-nitro aniline liberated in the supernatant was measured as the difference in optical density at $410 \mathrm{~nm}$, between samples, with and without substrate. The substrate incubated in the absence of homogenate under the same condition was used as a reference blank. The enzyme activity was expressed as IU/mg of protein.

\subsection{1, Assay of 5'- Nucleotidase (5'-NT)}

5'-Nucleotidase was assayed by the method of Fine et al, [22]. The assay medium in a total volume of $2.0 \mathrm{~mL}$ contained $1.2 \mathrm{~mL}$ of Tris- $\mathrm{HCl}$ buffer $(\mathrm{pH} 7.5,184 \mathrm{mM}), 0.2 \mathrm{~mL}$ magnesium sulfate $(50 \mathrm{mM}), 0.2 \mathrm{~mL}$ potassium chloride $(650 \mathrm{mM}), 0.2 \mathrm{~mL}$ of EDTA $(1 \mathrm{mM})$ and $0.2 \mathrm{~mL}$ of 5 -AMP $(40 \mathrm{mM})$. The reaction was initiated by the addition of $0.2 \mathrm{~mL}$ of sample and incubated at $37^{\circ} \mathrm{C}$ for $15 \mathrm{~min}$. The reaction was terminated by the addition of $2.0 \mathrm{~mL}$ of TCA. After centrifugation, phosphorus in the supernatant was estimated by the method of Fiske and Subbarau [23]. The enzyme activity was expressed as IU/mg of protein.

\subsection{2, Assay of cathepsin D (CD)}

The activities of cathepsin D was assayed by the method described by Shamberger [24]. To $0.8 \mathrm{~mL}$ of sodium formate buffer $\mathrm{pH} 3.5(0.2 \mathrm{M}), 1.0 \mathrm{~mL}$ of acid denatured haemoglobin, $1.5 \%$ and $0.2 \mathrm{~mL}$ of enzyme were added and incubated for $2 \mathrm{~h}$. The reaction was terminated by the addition of $2.0 \mathrm{~mL}$ of $10 \%$ of TCA. Control received enzyme after the addition of TCA. After $30 \mathrm{~min}$ centrifuged at $1000 \mathrm{rpm}$ for $5 \mathrm{~h}$. Sodium carbonate in sodium hydroxide $2.5 \mathrm{~mL}$ was added to the supernatant and mixed well. Folin's phenol, $0.5 \mathrm{~mL}$ was added and mixed immediately. Standard containing aliquots of tyrosine blank containing water was treated similarly. The blue colour developed was read at $670 \mathrm{~nm}$. Enzyme activities were expressed as $\mu$ moles of tyrosine released/hr/mg protein.

\subsection{3, Hydrolysis of tissue glycoconjugates}

To $200 \mathrm{mg}$ of tissue, $5.0 \mathrm{~mL}$ of $90 \%$ ethanol was added. It was kept over night, homogenized and centrifuged. The supernatant was removed, $2.0 \mathrm{~mL}$ of $4 \mathrm{~N} \mathrm{HCl}$ was added and hydrolysed at $100^{\circ} \mathrm{C} \mathrm{for} 4 \mathrm{~h}$. Then it was neutralized with $2.0 \mathrm{~mL}$ of $4 \mathrm{~N} \mathrm{NaOH}$. Aliquotes of the hydrolysate were taken for the analysis.

\subsection{4, Estimation of Hexose}

Hexose was estimated by the method of Niebes [25]. To $0.5 \mathrm{~mL}$ of neutralized sample, $0.5 \mathrm{~mL}$ of water, $7.0 \mathrm{~mL}$ of orcinol-sulphuric acid reagent $(1.6 \mathrm{~g}$ orcinol in 100 of water, $1.0 \mathrm{~mL}$ of this was mixed with $7.5 \mathrm{~mL}$ of sulphuric acid - water mixture, $3: 2 \mathrm{v} / \mathrm{v}$ ) were added very slowly to the tubes in the cold condition. The tubes were heated at $80^{\circ} \mathrm{C}$ for $15 \mathrm{~min}$, cooled and read at $540 \mathrm{~nm}$ after $20 \mathrm{~min}$ in a Hitachi 320 spectrophotometer.

\subsection{5, Estimation of Hexosamine}

Hexosamine was estimated by the method of Wagner [26]. To $0.8 \mathrm{~mL}$ of the neutralized samples, 0.6 $\mathrm{mL}$ of acetyl acetone reagent (3.5\% acetyl acetone was prepared in $1 \mathrm{~N}$ trisodium phosphate and $0.5 \mathrm{~N}$ potassium tetraborate mixed in the ratio of $98: 2 \mathrm{v} / \mathrm{v}$ ) was added. The tubes were heated in a boiling water bath for $30 \mathrm{~min}$ and were cooled and $2.0 \mathrm{~mL}$ of Ehrlich's reagent $(320 \mathrm{mg}$-dimethyl aminobenzaldehyde was dissolved in $2.0 \mathrm{~mL}$ of concentrated $\mathrm{HCl}$ ) were added. All the tubes were shaken well and read at $540 \mathrm{~nm}$ in Hitachi 320 spectrophotometer.

\subsection{6, Estimation of Fucose}

Fucose was estimated by the method of Winzler [27]. To $1.0 \mathrm{~mL}$ of tissue sample in a tube, $5.0 \mathrm{~mL}$ of $95 \%$ ethanol was added, mixed and centrifuged. The precipitated was suspended in $5.0 \mathrm{~mL}$ of $95 \%$ ethanol, centrifuged and decanted. Then the precipitate was dissolved in $1.0 \mathrm{~mL}$ of $0.1 \mathrm{~N} \mathrm{NaOH}(1.0 \mathrm{~mL}$ water for blank and $1.0 \mathrm{~mL}$ fucose for standard), placed in an ice-bath and $4.5 \mathrm{~mL}$ of cold $\mathrm{H}_{2} \mathrm{SO}_{4}$ mixture $(6.1 \mathrm{v} / \mathrm{v})$ was added and mixed well. The tubes were heated in a boiling water bath for $3 \mathrm{~min}$ and cooled. Cysteine, $0.1 \mathrm{~mL}$ of $3 \%$ was added and mixed immediately. The tubes were allowed to stand at room temperature for 60-90 min. The absorbance of the solution at 396 and $430 \mathrm{~nm}$ was measured in a Hitachi 320 spectrophotometer and the difference in absorbance was taken for calculation. 


\subsection{8, Estimation of Sialic acid}

The LSA (Lipid-bounded Sialic Acid) was measured as suggested by Ketopodies et al. [28]. $50 \mu \mathrm{L}$ of tissue sample was extracted with chloroform-methanol $(2: 1 \mathrm{v} / \mathrm{v})$ maintained at $4{ }^{\circ} \mathrm{C}$. The lipid was extracted with $0.5 \mathrm{~mL}$ of cold distilled water. The aqueous layer was precipitated with phosphototungstic acid. The precipitates were resuspended in $1.0 \mathrm{~mL}$ of following reagent $\left(1.0 \mathrm{~mL}\right.$ of $2 \%$ resorcinol in water, $0.25 \mathrm{~mL}$ of $0.1 \mathrm{M} \mathrm{CuSO}_{4}$ and $9.75 \mathrm{~mL}$ of water were added and made up to $100 \mathrm{~mL}$ with concentrated hydrochloric acid) was added, mixed and placed in a boiling water bath for $15 \mathrm{~min}$. The tubes were cooled, $2.0 \mathrm{~mL}$ of butylacetate:butanol mixture $(85: 15, \mathrm{v} / \mathrm{v})$ was added and vortexed. After centrifugation, the blue colour of the organic layer was read at $580 \mathrm{~nm}$ in the Hitachi 320 spectrophotometer.

\subsection{9, Statistical analysis}

All data were analyzed with SPSS / 10 student software hypothesis testing methods included one way Analysis of Varience (ANOVA) followed by LSD. The values are expressed as mean \pm SD, P value of less than 0.05 was considered to indicate statistical significance.

\section{1, Ultra Violet spectrum (UV)}

\section{Results}

The UV spectrum of the compound AA at $\lambda_{\max } 322,394(\log \Sigma$ 4.17, 3.92) "Fig.1" and showed characteristics of aristolochic acid.

\section{2, Infra Red Spectrum (IR)}

The IR spectrum of the compound AA "Fig. 2" showed peaks at $3390 \mathrm{~cm}^{-1}$ due to $\mathrm{OH}$ group, 2919 $\mathrm{cm}^{-1}, 2850 \mathrm{~cm}^{-1}$ due to C-H stretching, $1705 \mathrm{~cm}^{-1}$ due to -C-in aryl carboxylic acid, $1362 \mathrm{~cm}^{-1}$ due to $\mathrm{NO}_{2}$ group. The above data indicated that the compound contained $\mathrm{OH}, \mathrm{C}-\mathrm{H},-\mathrm{C}$ - aryl carboxylic acid, $\mathrm{NO}_{2}$ nitro groups and aromatic in nature.

\section{3, ${ }^{1} \mathrm{H}$-Nuclear Magnetic Resonance Spectrum $\left({ }^{1} \mathrm{H}-\mathrm{NMR}\right)$}

${ }^{1} \mathrm{H}$-NMR spectrum of the compound AA showed "Fig. 3" the following details. The compound AA exhibited a singlet at $\delta 4.09$ due to the -OH protons. Another singlet at $\delta 6.45$ due to $-\mathrm{O}_{-}-\mathrm{CH}_{2}-\mathrm{O}-$ protons. A doublet between $\delta$ 7.24-7.26 $(\mathrm{J}=8.3 \mathrm{~Hz})$ due to $\mathrm{C}_{7}$ proton. A triplet between $\delta 7.75-7.79(\mathrm{~J}=8.3 \mathrm{~Hz})$ due to $\mathrm{C}_{6}$ proton. A sharp singlet at $\delta 7.77$ is due to $\mathrm{C}_{2}$ proton. A singlet at $\delta 8.06$ may be due to -OH proton. A singlet at $\delta$ 8.65 is due to $\mathrm{C}_{9}$ proton. A doublet at $\delta 8.69-8.71(\mathrm{~J}=8.3 \mathrm{~Hz})$ due to $\mathrm{C}_{5}$ proton.

\section{4, ${ }^{13}$ C-Nuclear Magnetic Resonance Spectrum $\left({ }^{13} \mathrm{C}-\mathrm{NMR}\right)$}

${ }^{13} \mathrm{C}-\mathrm{NMR}$ spectrum of compound AA showed "Fig. 4" the presence of all the 17 carbons. ${ }^{13} \mathrm{C}-\mathrm{NMR}$ showed the following details. A peak at $\delta 170.12$ due to carbonyl carbon. A peak at $\delta 159.21$ and 149.45 due to phenoxy carbon. A peak at 107.75 due to $-\mathrm{O}-\mathrm{CH}_{2}-\mathrm{O}$ - carbon. A peak at $\delta 856.11$ due to methoxy carbon. The six aromatic atoms appeared at $\delta 106.12,117.63,125.53,133.64,134.51$ and 137.22 respectively. The predicted structure of aristolochic acid was showed in "Fig. 5".

\section{5, Mass spectrum}

In Mass spectrum, the molecular ion peak was observed at 341 m/e "Fig. 6" for AA isolated from A. indica. Molecular formula of $\mathrm{C}_{17} \mathrm{H}_{11} \mathrm{NO}_{7}$ and molecular weight of 341.28 were recorded.

\section{6, Effect of AA on oral cancer}

The effect of AA on 4-NQO induced oral cancer was studied. There was a significant decrease in percentage of tumor (50.0\%), number of tumors (3.66) and tumor volume (77.85) in AA treatment against tumor induced by $4-\mathrm{NQO}$ in rats, when compared to the oral cancer induced rats respectively $(66.67 \%, 4.02,105.60)$ "Table 1".

\section{7, Effect of AA on body weight and liver weight}

The effect of AA on body weight and liver weight of rats induced with oral cancer by 4-NQO was studied. The body weight was $112 \mathrm{~g}$ and liver weight was $4.23 \mathrm{~g}$ in oral cancer induced rats. Significant increase in the body weight (133 g) and significant decrease in the liver weight (3.98) were observed in oral cancer induced rats after the treatment of AA. No significant changes were found when control was the compared with AA alone treated rats "Table 2". 


\section{8, Effect of AA on tumor markers}

The effect of AA on neoplastic markers in control and experimental rats are presented in Table 3. There was significant decrease in the activity of GST and significant increase $(\mathrm{p}<0.05)$ in all other markers (GGT, CD, 5'-NT) in oral cancer induced rats when compared with control rats. Significant increase in the activity of GST and a significant decrease in all other markers were observed in oral cancer and AA treated rats when compared with oral cancer induced rats $(\mathrm{p}<0.05)$. There was no significant change with that of AA alone treated rats when compared with control rats "Table 3".

\section{9, Effect of AA on cell surface glycoconjugates}

The effect of AA on cell surface glycoconjugates level in control and experimental rats were studied. There was significant increase in the level $(\mathrm{p}<0.05)$ of glycoproteins in oral cancer induced rats when compared with control rats. There was a significant decrease in the levels of glycoproteins with that of oral cancer AA treated rats. There was no significant change in AA alone treated rats when compared with control rats "Table $4 "$.

Histological studies were carried to find out the effect of AA on oral cancer induced rats. The control group showed intact layer of epithelium (Fig. 6a). In oral cancer induced rats, the tongue mucosa was found to be hyperplastic squamous epithelium, hyperkeratosis and had keratin cyst formation (Fig. 6b). On treatment with aristolochic acid on oral cancer induced rats, the mucosa showed papliomatous configuration, the appearance was found to be that of degenerated papiloma and the center core was completely hyaline with displaced cell basal activity and necrosis (Fig. 6c). Aristolochic acid (AA) alone treated groups showed similar architecture to that of control rats (Fig. 6d).

\section{Discussion}

Aristolochic acid has been found to inhibit breast cancer in rats and study carried out and proved that AA to be a tumor inhibitor. So in the present study, we studied the therapeutic effect of AA on 4-NQO induced oral cancer. The UV, IR, NMR and MASS spectral studies were reveled that the purity, maximum wavelength, nature, functional groups, structure and molecular weight of the compound AA was confirmed. GGT is a marker of neoplastic progression and occurs in a number of human malignant neoplasm and their metastasis [29]. The physiological function of GGT is closely connected with the metabolism and transport of glutathione. GSH is exported to the blood plasma and it is broken down by GGT. The products are transported and utilized for GSH synthesis. Inhibition of GGT also interrupts "Salvage" pathway of GSH synthesis [30]. In the present study, the activity of GGT level was found to be increased $(29.0 \mathrm{IU} / \mathrm{mL}$ of tissue) in oral cancer induced by 4-NQO rats. When these rats were treated with AA, there was a decrease (19.8 IU/mL of tissue) level of GGT. This may be due to the tumor regressive effect of AA.

Glycoproteins and gylcolipids are the major constituents of cell membrane and hence, cell surface glycoconjugates are important in malignancy. Glycoproteins are usually defined apoproteins - carbohydrate complexes in which oligosaccharides and / or polysaccharides are joined by covalent linkage to specific amino acid of proteins. This carbohydrate portion contains amino sugars (glycosamines, galactosamines or sialic acid) and hexose (galactose, mannose) or fucose. These glycoconjugates are released into the circulation through increased turnover, secretion, and / or shedding from malignant cells. The increased levels are positively correlated with increasing stages in oral cancer [31]. The human tumor burden and progression of disease and reflected from the high levels of glycoproteins in oral cancer. Significantly higher levels of hexose and hexosamine have been reported in oral malignancy [32]. The elevated levels of hexose and hexoseamine in oral cancer may be the consequence of tissue necrosis, caused by rapidly spreading tumor cell destroying normal connective tissue. Fucose level is a better biochemical tumor marker than sialic acid level in oral cancer squamous cell carcinoma [33]. In the present study, there was a significant increase in glycoconjugates level in oral cancer induced rats, which correlated with the previous studies, which are given above. On treatment with AA, there was a significant decrease in the levels of glycoconjugates.

Cathepsin D is a prognostic indicator of metastasis in cancer [34]. High levels of cathepsin D in serum with patients of metastatic carcinoma have been detected, whereas low levels of cathepsin D have been detected in non-metastatic cancer [35]. In oral cancer induced animals, there was an increase in the activity of cathepsin D. The supplementation of aristolochic acid isolated from A. indica to the oral cancer induced rats resulted in a significant decrease in the activity of cathepsin $\mathrm{D}$, which indicate the inhibition of metastasis by aristolochic acid. The study of Murray et al. [36] showed the increased GGT and 5'nucleotidase enzymes in the cancer conditions. In the present study also there was an increased levels of GGT and 5'-nucleotidase (19.4 IU/mg of protein; $13.4 \mathrm{IU} / \mathrm{mg}$ of protein) cancer induced rats. But this was reduced (15.9 IU/mg of protein; $9.8 \mathrm{IU} / \mathrm{mg}$ of protein) when AA treatment was given.

The compound AA treatment $(1.0-2.0 \mathrm{mg} / \mathrm{kg} / \mathrm{d}$ ip) short-term toxic effect which include hepatotoxicity, marked renal damage and mild hematological dyscrasias were observed in rats. In the present study, 10 
$\mathrm{mg} / \mathrm{kg} / \mathrm{b}$. wt of AA was given orally to the normal rats and they were found to be like the normal rats and also no symptom of toxicity was observed. The results suggest that the activity of AA may be slow when administered orally or there may be changes in the biochemical pathways. Further work on this line may be useful for know the machanism. The results of the present study strongly supported the use of AA isolated from A. indica as a partial anticancer drug.

\section{Conclusion}

In conclusion, Aristolochia indica a medicinal plant possesses the important natural anticancer compound aristolochic acid that renders it a potent anticancer drug for oral cancer. Thus the claim made by the traditional Indian systems of medicine regarding the use of this plant in the treatment of initial stage of oral cancer.

\section{Acknowledgments}

Author is grateful to Head, Department of Biochemistry, University of Madras for providing all the requirements regarding this research.

\section{References}

[1] F Gonzalez, Inflorescence morphology and the systematics of Aristolochiaceae. Syst. Geogr. Pl. 68, 1999, $159-172$.

[2] Nortier JL, Mc. M. Martinez, H.H. Scheiser, V.M. Arlt, C.A. Bieler, M. Petein, M.F. Depierreux, L. De Pauw, D. Abramowitz, P. Vereerstraeten, J.L. Vanherweghem, Urothelial carcinoma associated with the use of a Chinese herb (Aristolochia fangchi). New England Journal of Medicine, 342, 2000, 1686-1692.

[3] M Stiborova, E. Freib, H.H. Schmeiser, Aristolochic acids and the kidney disease called Chinese herbs nephropathy. Chemicke Listy, 94, 2000, 186-189.

[4] K Hashimoto, M. Higuchi, B. Makino, I. Sakakibara, M. Kubo, Y. Komatsu, M. Maruno, M. Okada, Quantitative analysis of aristolochic acids, toxic compounds, contained in some medicinal plants. J. Ethnopharmacol., 64, 1999, $185-189$.

[5] LT Angeles, B.D. Canlas, J.A. Concha, A.S. Sotto, P.L. Aligaen, Toxicity studies on aristolochic acid isolated from Aristolochia Tagala, Cham. Acta Med Philipp., 6, 1970, 139-148.

[6] A Pakrashi, P. Pakrasi, Antifertility efficacy of the plant Aristolochia indica Linn on mouse. Contraception, 20, 1979, 49-54.

[7] CT Che, M.S. Ahmed, S.S. Kang, D.P. Waller, A.S. Bingel, A. Martin, P. Rajamahendran, N. Bunyapraphatsara, D.C. Lankin, G.A. Cordell, Studies on Aristolochia III. Isolation and biological evaluation of constituents of Aristolochia indica roots for fertilityregulating activity. Journal of Natural Products, 47, 1984, 331-341.

[8] T Ganguly, A. Pakrashi, A.K. Pal, Disruption of pregnancy in mouse by aristolic acid: I. Plausible explanation in relation to early pregnancy events. Contraception, 34, 1986, 625-637.

[9] TS Wu, L.F. Ou, C.M. Teng, Aristolochic acids, aristolactam alkaloids and amides from Aristolochia kankauensis. Phytochemistry, 36, 1994, 1063-1068.

[10] W Martz, Plants with a reputation against snakebite. Toxicon, 30, 1992, 1131-1142.

[11] VIE Baltatzis, I. Karydas, C. Pateras, Experimental application of herbs of Greek flora with anticancer properties in breast cancer in vitro and in rats in vivo. Anticancer Res., 12, 1992, 1883.

[12] SM Kupchan, H.C. Wormser, Tumor inhibitors X. Phytochemical synthesis of phenantherenes. Synthesis of aristolochic acid and related compounds. Indian Journal of Organic Chemistry, 11, 1965a, 3792-3800.

[13] SM Kupchan, H.C. Wormser, Tumor inhibitors IX. Synthesis of 10-nitro-1-phennthronic acid. Indian Journal of Organic Chemistry, 11, 1965b, 3933-3934.

[14] I McGrath, J. Litvak, Cancer in developing countries: opportunity and challenge. J. Natl. Cancer Inst., 85, $1993,862-874$.

[15] C Boring, T.S. Squrils, T. Tong, Cancer statistic, CA. Cancer J. Clin., 42, 1992, 19-38.

[16] CL Vecchia, A. Tavani, S. Flanceshi, F. Levi, G. Corran, E. Negi, Epidemiology and prevention of oral cancer. Oral Oncol., 33, 1997, 302-312.

[17] S Takashi, Multistep carcinogenesis: A 1992 prospective. Science, 258, 1992, 603-607.

[18] G Stenman, Malignancy of 4-NQO induced oral squamous cell carcinomas in rat. Acta Otolaryngol., 92,1981 557-561.

[19] SM Kupchan, J.J. Merianos, The isolation and structural elucidation of novel derivatives of aristolochic acid from Aristolochia indica. The Journal of Organic Chemistry, 33, 1968, 3735-3738.

[20] WH Habig, B. Jackobyus, Glutathion-S-transferase, The first enzymatic step in mercapturic acid formation. J. Biol. Chem., 249, 1981, 7130-7139.

[21] SB Rosalki, D. Rau, Serum gamma glutamyl transpeptiase activity in alcoholisum. Adv.Cli.Chem., 17, $1972,53$.

[22] C Fine, P.L. Ipata, C.A. Palmerini, A. Floridi, 5'-nucleotidase from bull plasma. Biochem. Biophys. Acta, 748, 1983, 405-412.

[23] CH Fiske, Y. Subbarau, Colorimetric determination of phosphorus. J. Biol. Chem., 66, 1925, 375-385.

[24] RJ Shamberger, Lysosomal enzyme changes in growing and regressing tumours. Biochem. J., 111, 1963, 373-383.

[25] P Niebes, Determination of enzymes and degradation products of glycosaminoglycans metabolism in the serum of healthy and varicose subject. Clin. Chem. Acta, 42, 1972, 399-408.

[26] WD Wagner, A more sensitive assay discriminating galactosamine and glucosamine in mixtures. Anal. Biochem., 94, 1979, 394398.

[27] R Winzler, Determination of serum glycoproteins, Methods Biochem. Anal., 2, 1968, 279-311.

[28] N Kalopotodies, Y. Hirashaut, L.G. Nancy, C.C. Stock, Lipid-associated sialic acid test for the detection of human cancers. Cancer Res., 42, 1982, 5270-5275.

[29] GP Sachdev, G. Wen, B. Nartin, G.S. Kishore, O.F. Fox, Effect of diety fat and $\alpha$-tocophared on GGT activity of 7, 12, dimethyl lunz (a) anthrazine induced mammaly gland adinocarcinomas. Cancer Biochem. Biophys., 5, 1980, 15-23.

[30] E. Ristoff, A. Larsson. Patients with syntan deflect in gamma glutamyl cycle. Chem. Biol. Interact., 11: 1998, 113-121.

[31] BR Baxi, P.S. Patel, Adhvaryan, P.K. Dayal, Usefulness of serum glycoconjugates in precancerous and cancerous diseases of the oral cavity. Cancer, 67, 1991, 735-740.

[32] D Sandore, C. Rorings, S. Jose, D. Panala, C. Inacio, Glycocongugates levels in the serum of 4-NQO induced oral cancer rats. Rev. Brass Med. Biol., 10, 1977, 247-249. 
[33] MC Shashikanth, R.B. Rao, Studies of serum fucose and serum sialic acid levels in oral squamoss cell carcinoma. Ind. J. Dent. Res., 5, 1994, 119-124.

[34] MJ Duffy, Protease as prognostic markers in cancer. Clin. Cancer Res., 2, 1996, 613-618.

[35] MK Schwartz, Tissue Cathepsins as tumor markers. Clin. Chem. Acta, 237, 1998, 67-78.

[36] JL Murray, M.P. Lerner, R.E. Earle, Elevation gamma glutamyl transpeptidase levels in malignant melanoma. Cancer, 49, 1982, 1439-1443.

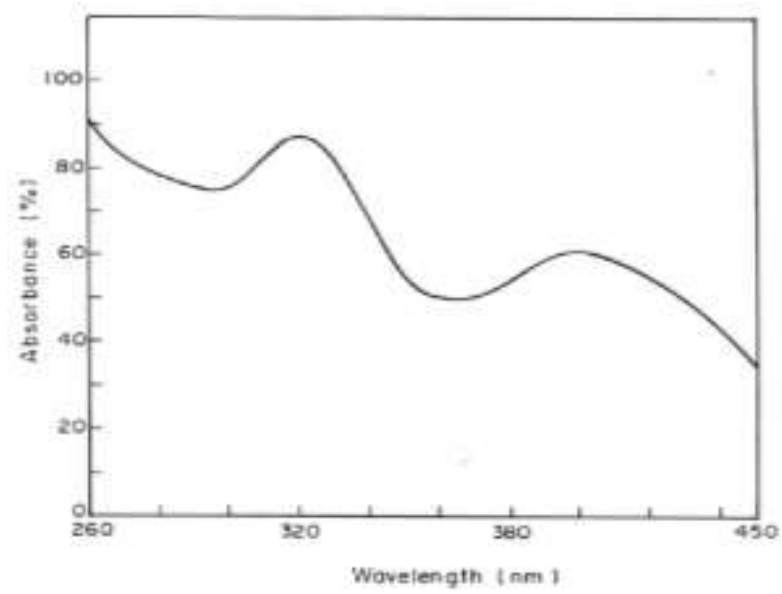

Figure 1. UV spectrum of aristolochic acid

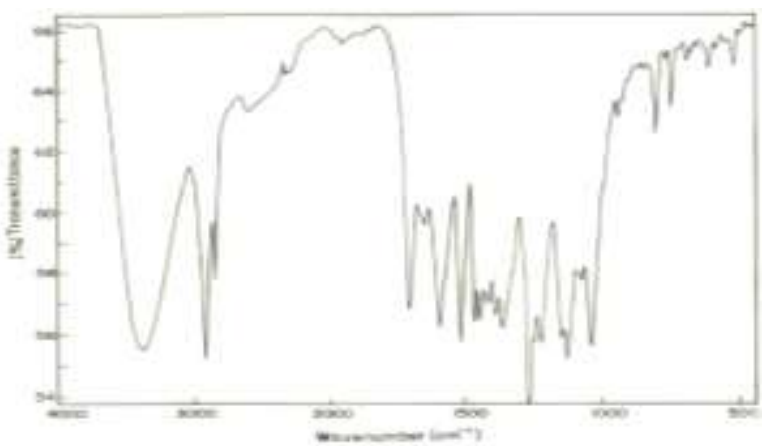

Figure 2. IR spectrum of aristolochic acid

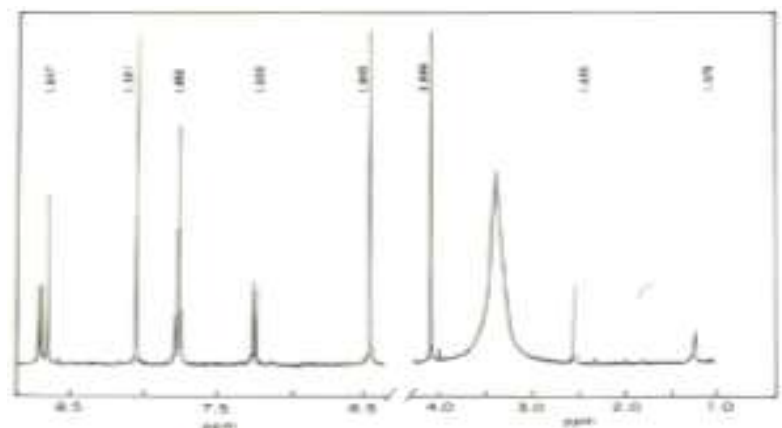

Figure 3. ${ }^{1} \mathrm{H}-\mathrm{NMR}$ spectrum of aristolochic acid

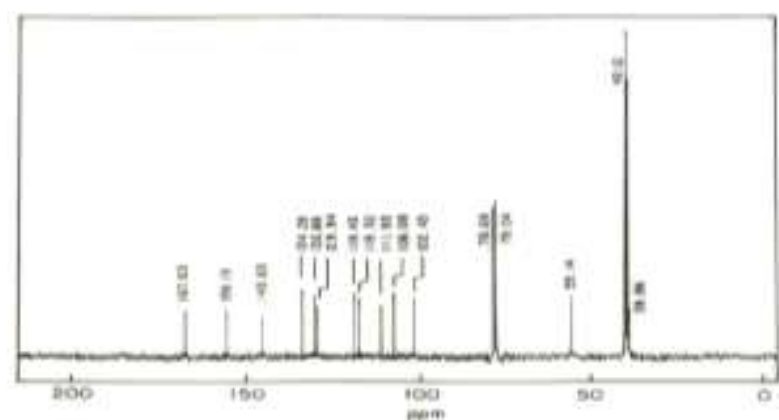

Figure $4 .{ }^{13} \mathrm{C}$-NMR spectrum of aristolochic acid 
<smiles>COc1cccc2c1cc([N+](=O)[O-])c1c(C(=O)O)cc3c(c12)OCO3</smiles>

Figure 5. Structure of aristolochic acid, molecular formula: $\mathrm{C}_{17} \mathrm{H}_{11} \mathrm{NO}_{7}$, Molecular weight: 341.28.

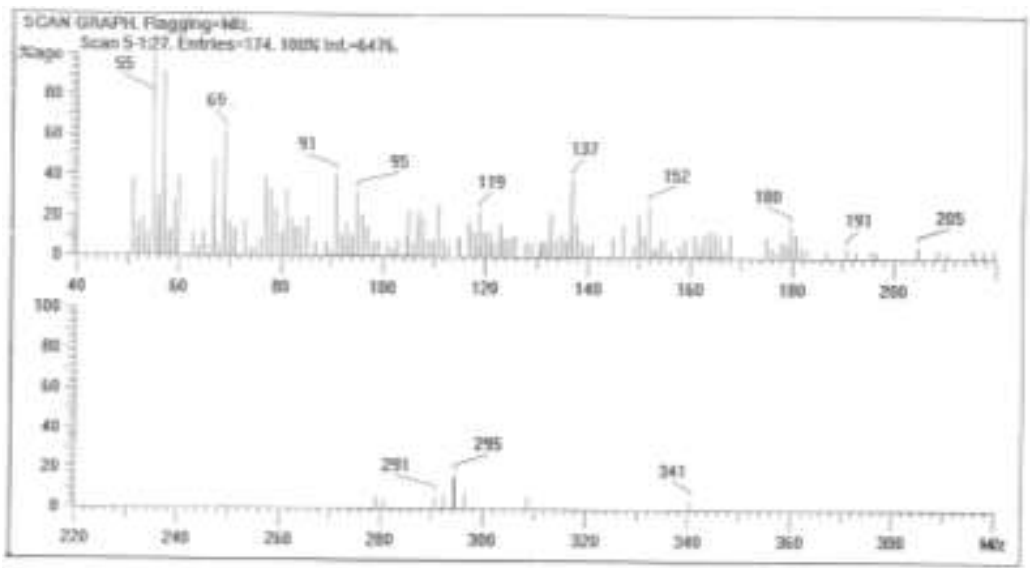

Figure 6. Mass spectrum of aristolochic acid

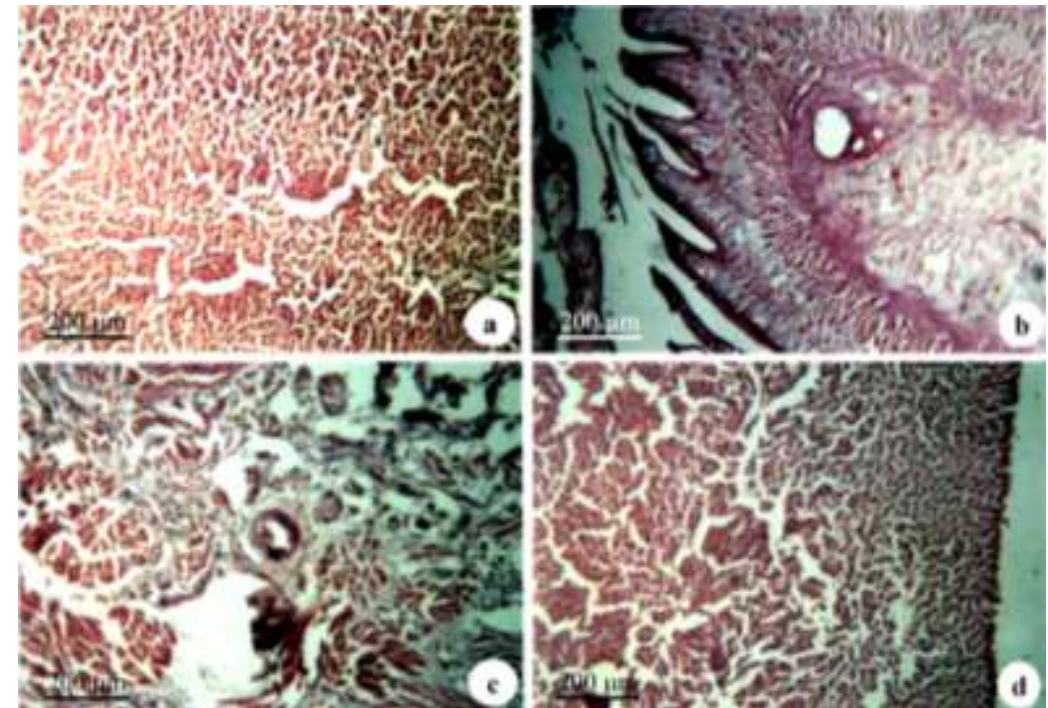

Figure 7. Effect of anticancer activity of aristolochic acid isolated from Aristolochia indica in rats.

a. Control shows the normal architecture.

b. 4-NQO induced oral cancer: Hyperplastic squamous epithelium, hyperkeratosis, keratin cyst formation, which are characteristic features of oral cancer.

c. 4-NQO induced oral cancer upon treatment with aristolochic acid: Degeberated papilloma, the center core of tumor was completely hyalinezed with displaced basal cell activity and necrosis.

d. Aristolochic acid alone treated shows similar architecture to control. 
Table 1. Effect of AA on tumor incidence, numbers of tumor and tumor volume 4-NQO induced oral cancer.

\begin{tabular}{lcccc}
\hline & \multirow{2}{*}{$\begin{array}{c}\text { No. of animals } \\
\text { examined }\end{array}$} & \% of Tumor & No. of tumor & $\begin{array}{c}\text { Tumor Volume } \\
\left(\mathrm{mm}^{3}\right)\end{array}$ \\
\cline { 3 - 5 } & 6 & 0 & 0 & 0 \\
I. Control & 6 & 66.67 & $4.02 \pm 0.48$ & $105.60 \pm 2.23$ \\
II. 4-NQO & 6 & 0 & 0 & 0 \\
III. AA & 6 & $50.00^{*}$ & $3.66 \pm 0.30^{*}$ & $77.85 \pm 5.43^{*}$ \\
IV. 4-NQO + AA (post) & & &
\end{tabular}

Results are expressed as mean \pm SD, $*$ Significant difference ( $p<0.05$, LSD) compared with group II (4-NQO). Tumor volume $\left(\mathrm{mm}^{3}\right)$ was calculated by the formula- $4 / 3 \pi \mathrm{r}^{3}(\mathrm{r}$-represents the average radius of three diameter measurement in $\mathrm{mm}$ )

Table 2. Effect of AA on body weight and liver weight of rats induced oral cancer by 4-NQO.

\begin{tabular}{lccc}
\hline Group (treatment) & $\begin{array}{c}\text { No of animals } \\
\text { examined }\end{array}$ & $\begin{array}{c}\text { Body weight } \\
(\mathrm{g})\end{array}$ & $\begin{array}{c}\text { Liver weight } \\
(\mathrm{g})\end{array}$ \\
\hline I. Control & 6 & $171 \pm 16$ & $3.70 \pm 0.31$ \\
II. 4-NQO & 6 & $112 \pm 14^{\mathrm{a}}$ & $4.23 \pm 0.32^{\mathrm{a}}$ \\
III. AA & 6 & $173 \pm 17^{\mathrm{ns}}$ & $3.72 \pm 0.32^{\mathrm{ns}}$ \\
IV. 4-NQO + AA (post) & 6 & $133 \pm 15^{\mathrm{b}}$ & $3.98 \pm 0.42^{\mathrm{b}}$ \\
\hline
\end{tabular}

Results are expressed as mean \pm SD, a and b Significantly different ( $\mathrm{p}<0.05$, LSD) when compared with group II (4-NQO) and group IV (4-NQO).

On comparing group I with group II and group III with group IV

Ns - non significant - on comparing group I with group III.

Table 3. Effect of AA on control and experimental rats.

\begin{tabular}{lcccc}
\hline \multicolumn{1}{c}{ Parameters } & $\begin{array}{c}\text { Group - I } \\
\text { (Control) }\end{array}$ & $\begin{array}{c}\text { Group - II } \\
(4-\mathrm{NQO})\end{array}$ & $\begin{array}{c}\text { Group - III } \\
\text { (AA) }\end{array}$ & $\begin{array}{c}\text { Group - IV } \\
(4-N Q O\end{array}$ \\
\hline GST & $120.4 \pm 0.1$ & $163.9^{\mathrm{a}} \pm 3.3$ & $119.5^{\mathrm{ns}} \pm 1.0$ & $139.3^{\mathrm{b}} \pm 3.3$ \\
GGT & $12.7 \pm 0.5$ & $19.4^{\mathrm{a}} \pm 0.9$ & $12.5^{\mathrm{ns}} \pm 0.4$ & $15.9^{\mathrm{b}} \pm 0.5$ \\
CD & $90.3 \pm 0.2$ & $112.7^{\mathrm{a}} \pm 0.8$ & $88.4^{\mathrm{ns}} \pm 0.5$ & $101.6^{\mathrm{b}} \pm 0.3$ \\
$5^{\prime}-\mathrm{NT}$ & $5.2 \pm 0.6$ & $13.4^{\mathrm{a}} \pm 0.5$ & $4.9^{\mathrm{ns}} \pm 0.6$ & $9.8^{\mathrm{b}} \pm 0.3$ \\
\hline
\end{tabular}

Values were expressed as mean \pm S.D.

Comparisons: a, b, significantly different from Group-I, Group-II respectively Group-I, Group-III was non significant at $\mathrm{P}<0.05$ (LSD)

Units of expression:

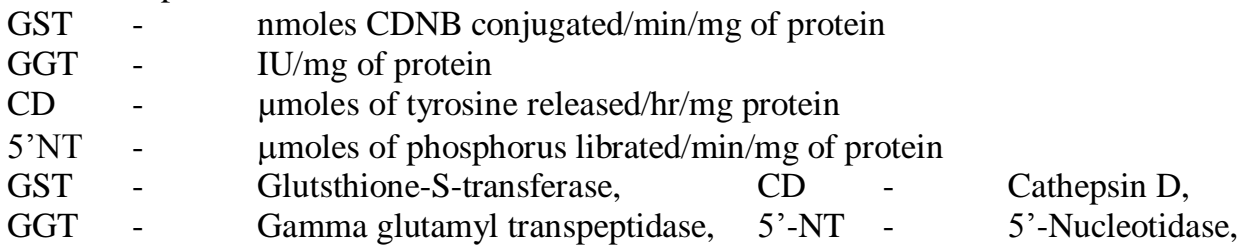

Table 4. Effect of AA on glycoprotein in control and experimental rats.

\begin{tabular}{lcccc}
\hline \multicolumn{1}{c}{ Parameters } & $\begin{array}{c}\text { Group - I } \\
(\text { Control })\end{array}$ & $\begin{array}{c}\text { Group - II } \\
(4-N Q O)\end{array}$ & $\begin{array}{c}\text { Group - III } \\
(\text { AA })\end{array}$ & $\begin{array}{c}\text { Group - IV } \\
(4-N Q O+\text { AA })\end{array}$ \\
\hline Hexose & $96.1 \pm 0.2$ & $124.7^{\mathrm{a}} \pm 0.7$ & $94.2^{\mathrm{ns}} \pm 1.0$ & $105.4^{\mathrm{b}} \pm 0.4$ \\
Hexosamine & $110.2 \pm 0.8$ & $135.5^{\mathrm{a}} \pm 0.6$ & $111.8^{\mathrm{ns}} \pm 3.6$ & $126.1^{\mathrm{b}} \pm 4.1^{\mathrm{n}}$ \\
Fucose & $120.4 \pm 0.1$ & $163.9^{\mathrm{a}} \pm 3.3$ & $119.5^{\mathrm{ns}} \pm 1.0$ & $139.3^{\mathrm{b}} \pm 3.3$ \\
Sialic acid & $123.8 \pm 1.7$ & $177.2^{\mathrm{a}} \pm 0.9$ & $122.9^{\mathrm{ns}} \pm 1.6$ & $146.9^{\mathrm{b}} \pm 1.5$ \\
\hline
\end{tabular}

Values were expressed as mean \pm S.D.

Comparisons: a, b, significantly different from Group-I, Group-II respectively

Group-I, Group-III was non significant at $\mathrm{P}<0.05$ (LSD)

Units - $\quad \mu \mathrm{g} / \mathrm{mg}$ of tissue 